\title{
A matter of quality: Kurt Goldstein's assessment of the abstract attitude after brain damage
}

\author{
Una cuestión de calidad: El examen de Kurt Goldstein de la actitud abstracta después de \\ un daño cerebral
}

Stefan FRISCH ${ }^{1,2}$, Alexandre MÉTRAUX ${ }^{3}$

\begin{abstract}
Neurologist and psychiatrist Kurt Goldstein (1878-1965) made substantial contributions to neuropsychology in general and to the development of tests for the assessment of brain damage sequelae in particular. Unlike present-day neuropsychology's psychometric orientation, Goldstein kept a critical distance to a mere quantitative evaluation. Eighty years ago, he impressively demonstrated his own, qualitatively oriented diagnostic approach both in a remarkable monograph and in a didactic film, in collaboration with psychologist Martin Scheerer (1900-1961). By modifying a classical paradigm for the assessment of deficits in visuospatial construction, the Block Design Test, the two authors developed the Goldstein-Scheerer Cube Test. This version characterizes itself by offering the patient different types of cues in order to reveal the nature of the deficit at stake. The test remains an impressive illustration of Goldstein's most famous neuropsychological concept, viz. the human ability to abstract from a concrete situation: the abstract (or categorial) attitude.
\end{abstract}

Keywords: Kurt Goldstein; Neuropsychological Tests; Neurocognitive disorders; Abstract attitude.

\section{RESUMEN}

El neurólogo y psiquiatra Kurt Goldstein (1878-1965) hizo contribuciones sustanciales a la neuropsicología en general y al desarrollo de tests para el examen de las secuelas de daños cerebrales en particular. Contrariamente a la actual orientación psicométrica de la neuropsicología, Goldstein mantuvo una distancia crítica hacia una mera evaluación cuantitativa. Hace ochenta años, demostró de manera impresionante su propio enfoque diagnóstico cualitativo en una notable monografía y en una película didáctica, en colaboración con el psicólogo Martin Scheerer (1900-1961). Mediante la modificación de un paradigma clásico para la evaluación de déficits en la construcción visual espacial, el test de diseño en bloques, estos autores desarrollaron el test de cubo Goldstein-Scheerer. Esta versión se caracteriza por ofrecer tipos graduados de ayuda al paciente individual para revelar la naturaleza del déficit en juego. Además, la prueba sigue siendo una impresionante ilustración del concepto más famoso de Goldstein, a saber, la capacidad humana para abstraer de una situación determinada: la actitud abstracta.

Palabras clave: Kurt Goldstein; Test neuropsicológicos; Déficits neurocognitivos; Actitud abstracta.

Clinical neuropsychology seems crazy about numbers: Cognitive abilities have to be quantified and normed in order to serve as a measure of an individual's performance relative to a population. A deviance may relate to a brain damage. An early critic of such a merely quantitative assessment was the German-American neurologist and psychiatrist Kurt Goldstein (1878-1965), one of the founders of holistic neurology and neuropsychology ${ }^{1,2}$. After having fled Nazi Germany, Goldstein worked in the USA where he published a remarkable monograph ${ }^{3}$ together with the psychologist Martin Scheerer (1900-1961). In this work, the authors proposed a qualitative test procedure for the assessment of cognitive deficits which they illustrated by means of a didactic film.

\footnotetext{
1Pfalzklinikum, Department of Gerontopsychiatry, Psychosomatic Medicine, and Psychotherapy, Klingenmünster, Germany. ${ }^{2}$ Goethe University, Institute of Psychology, Frankfurt am Main, Germany.

3Université de Lorraine, Archives Henri Poincaré, Nancy, France.

Stefan Frisch ${ }^{1,2}$ (D) https://orcid.org/0000-0002-7294-4786; Alexandre Métraux ${ }^{3}$ (D) https://orcid.org/0000-0003-2232-6290

Correspondence: Stefan Frisch; E-mail: stefan.frisch@pfalzklinikum.de

Conflict of interest: There is no conflict of interest to declare.

Authors' contributions: Both authors contributed equally to the writing, revising and final approval of the manuscript.

Received on January 07, 2021; Accepted on February 14, 2021
} 
The paradigm used by Goldstein and Scheerer is one among the earliest (neuro)psychological tests ${ }^{4}$, the Block Design Test. It is part of the Wechsler Adult Intelligence Scale (WAIS) and is still being widely used for the assessment of visuospatial construction in clinical neuropsychology ${ }^{5}$. Subjects are asked to arrange wooden cubes displaying three different types of color patterns on their sides (plain white, plain red or diagonally divided red and white, but older versions used different colors) according to a model on paper. The Gestalt of the target pattern has to be mentally segmented into parts corresponding to the different sides of the cubes which may then be arranged accordingly.

Visuospatial construction as tested by the Block Design Test is the ability to integrate sensory input into a spatial representation and to enable an adequate motor response in extrapersonal space ${ }^{5}$. Historically, visuospatial impairments have been classified under a variety of terms such as 'optic ataxia' or 'constructive apraxia'. They have proven valuable in the differential diagnosis of neurological conditions such as dementia ${ }^{7}$. However, the standard use of the Block Design Test (e.g., as part of the WAIS) in neuropsychology has been criticized, as it scores only the number of correct solutions and thus discards qualitative aspects of performance ${ }^{5,8}$. The usefulness of a qualitative analysis of Block Design Test performance of brain damaged patients has been repeatedly demonstrated ${ }^{9}$.

In this respect, Goldstein and Scheerer ${ }^{3}$ presented pioneering work. By way of some modifications of the original procedure ${ }^{4}$, they categorized different types of errors in patients' performance, such as size transformation (the model on paper being larger than the arrangement of blocks), mental segmentation of the model, and consideration of all relevant features (color and form), etc. Their test version seems profoundly unconventional in the eyes of psychometrically oriented neuropsychologists (see Figure 1): If an item was not correctly solved (Figure 1a), the following forms of graded help were offered: (i) Enlarged model matching the arrangement of blocks in size, thus no size transformation is demanded (Figure 1b). (ii) Original model with grid lines segmenting the model into the different cube sides (Figure 1c). (iii) The same with an enlarged design matching the block arrangement in size. (iv) Model as an arrangement of wooden blocks (Figure 1d). (v) The same as (iv) but with space between the blocks. (vi) Multiple choice among three models presented built from blocks. In case of success of any of these steps (i)-(vi), the original task was repeated in order to test the transfer of what had been learned. The patient's procedure was recorded in detail, including final block arrangements, strategy, and patient's comments and judgments.

Goldstein continuously objected to psychometric testing of neurological patients, since standardization and mere quantification would not reveal the actual impairment of the individual patient ${ }^{10}$. This does not contradict the fact that Goldstein was probably one of the first to administer a comprehensive and psychologically elaborated test battery to patients ever since being head of the Institute for Research into the Aftereffects of Brain Injury in Frankfurt am Main, a clinic for the rehabilitation of brain-damaged First World War veterans ${ }^{2}$. Goldstein repeatedly criticized the approach of nineteenth century neurology which he had first adopted as one of Carl Wernicke's (1848-1905) students. This approach focused exclusively on whether a task would be solved or not ${ }^{11}$. Goldstein argued that a correct solution could also have been achieved by means of some compensating strategy. Furthermore, just registering that a solution was incorrect would not reveal anything about the nature of the patient's deficit. A qualitative assessment was thus necessary as a prerequisite for successful rehabilitation. In addition, it could account for the idea that neuro(psycho)logical symptoms are intrinsically complex ${ }^{12,13}$ and dependent on the context of both the individual and the situation.

In contrast to nineteenth century mechanistic views of the brain, Goldstein regarded the brain as a Netzwerk (network $)^{11}$, i.e., a systemic whole. Any brain damage would break up and reduce this system's performance through destruction of cerebral tissue as well as disconnection effects. The remaining network would become less effective in holding and counterbalancing excitation by external stimuli. Hence, the patients' behavior would become more coarse-grained, stereotypical, and stimulus-bound. In Goldstein's terms, patients were forced to retain a concrete attitude towards the world, whereas intact brains allow us to refrain from immediate action and to reflect about the given situation, in short, to adopt an abstract (or categorial) attitude.

Goldstein considered the abstract attitude as an essential human ability ${ }^{10}$. He took its disturbance to be a Grundstörung (basic disturbance) resulting from brain damage or from severe mental illnesses such as schizophrenia ${ }^{14}$. Since the propensity to perform abstractions is anything but monolithic, Goldstein's and Scheerer's ${ }^{3}$ qualitative assessment aimed at grasping the severity of disturbance of the abstract attitude in a test of visuospatial construction. The abstract attitude being independent of stimulus modality, these authors presented another test in the same publication ${ }^{3}$, a precursor of modern sorting tests for the assessment of executive defi$\operatorname{cits}^{15}$. Goldstein's concept of the abstract attitude as a 'marker' of brain damage has been criticized as vague and unreliable for neuropsychological assessment ${ }^{16}$. Nevertheless, it remains a groundbreaking inspiration not only for neuropsychologists, but also philosophers ${ }^{17-19}$. In any case, Goldstein and Scheerer' ${ }^{3}$ urge for qualitative assessments in neuropsychology is at least as important today as it was 80 years ago. 


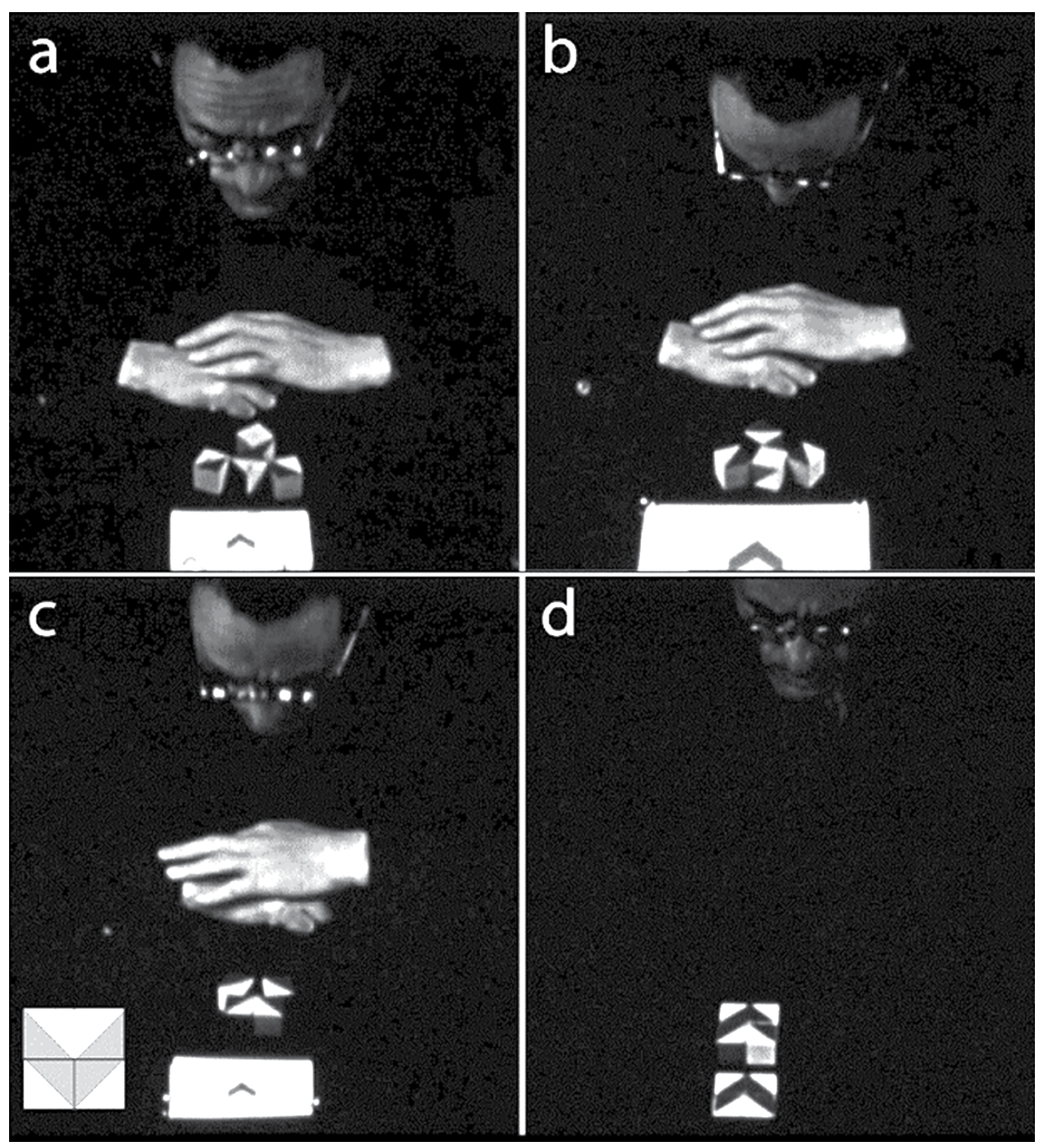

Figure 1. Illustration of how graded cues enhanced the diagnosis (according to type and severity) of disturbed abstract attitude in a brain-damaged subject. The patient was asked to arrange four wooden cubes. Their sides display patterns (plain blue, plain yellow, or diagonally divided blue and yellow) and have to be arranged according to a model presented on paper (GoldsteinScheerer Cube Test). The patient fails to solve the test item in its standard presentation (a). The patient does neither profit from a target pattern matching in size (b) nor from a target pattern with a grid of lines indicating the segmentation of the Gestalt (c; target pattern in lower left-hand corner added by the authors for illustration purposes). As the demand to abstract is minimized by giving the correct solution in its most concrete form, i.e., in the form of correctly arranged wooden cubes as in (d), the patient is able to reproduce the requested pattern. However, he is unable to transfer the solution in (d) to the original task (a). A severe disturbance of the abstract attitude has thus to be diagnosed. (Stills are taken from a film accompanying the monograph of Goldstein und Scheerer ${ }^{3}$ with kind permission of the Rare Book and Manuscript Library at Columbia University, New York. Figure is adapted from a previous publication ${ }^{20}$ ).

\section{REFERENCES}

1. Luria AR. Kurt Goldstein and neuropsychology. Neuropsychologia. 1966;4:311-3.

2. Eling P. Kurt Goldstein's test battery. Cortex. 2015 Feb;63:16-26. https://doi.org/10.1016/j.cortex.2014.08.002

3. Goldstein K, Scheerer M. Abstract and concrete behavior an experimental study with special tests. Psychol Monogr. 1941;53(2):1151. https://doi.org/10.1037/h0093487

4. Kohs SC. The block-design tests. J Exp Psychol. 1920;3(5):357-76.
5. Lezak MD, Howieson DB, Loring DW, Fischer JS. Neuropsychological assessment. New York: Oxford University Press; 2004.

6. Finger S. Origins of neuroscience: a history of explorations into brain function. New York: Oxford University Press; 2001.

7. Salimi S, Irish M, Foxe D, Hodges JR, Piguet O, Burrell JR. Can visuospatial measures improve the diagnosis of Alzheimer's disease? Alzheimers Dement (Amst). 2017 Nov 6;10:66-74. https://doi. org/10.1016/j.dadm.2017.10.004 
8. Troyer AK, Cullum CM, Smernoff EN, Kozora E. Age effects on block design: Qualitative performance features and extended-time effects. Neuropsychology. 1994;8(1):95-9. https://doi.org/10.1037/08944105.8.1.95

9. Wilde MC, Boake C, Sherer M. Wechsler Adult Intelligence ScaleRevised Block Design broken configuration errors in nonpenetrating traumatic brain injury. Appl Neuropsychology. 2000;7(4):208-14. https://doi.org/10.1207/S15324826AN0704_2

10. Goldstein K. The organism: A holistic approach to biology derived from pathological data in man. New York: Zone Books; 1995.

11. Goldstein K. Die Lokalisation in der Grosshirnrinde nach den Erfahrungen am kranken Menschen. In: Bethe A, editor. Handbuch der normalen und pathologischen Physiologie. Berlin: Springer; 1927. p. $600-842$.

12. Frisch $\mathrm{S}$. How cognitive neuroscience could be more biologicaland what it might learn from clinical neuropsychology. Front Hum Neurosci. 2014 Jul 21;8:541. https://doi.org/10.3389/ fnhum.2014.00541

13. Goldstein K. Das Symptom, seine Entstehung und Bedeutung für unsere Auffassung vom Bau und von der Funktion des Nervensystems. Arch Psychiat Nerven. 1926 Dec;76:84-108. https:// doi.org/10.1007/BF01814686
14. Bolles M, Goldstein K. A study of the impairment of "abstract behavior" in schizophrenic patients. Psychiatr Q. 1938;12:42-65. https://doi.org/10.1007/BF01563129

15. Eling P, Derckx K, Maes R. On the historical and conceptual background of the Wisconsin Card Sorting Test. Brain Cogn. 2008 Aug;67(3):247-53. https://doi.org/10.1016/j.bandc.2008.01.006

16. Teuber H-L. Kurt Goldstein's role in the development of neuropsychology. Neuropsychologia. 1966;4(4):299-310. https://doi. org/10.1016/0028-3932(66)90003-0

17. Métraux A. Philosophy, neurology, and the pathology of symbolic consciousness: on two unpublished letters from Ernst Cassirer to Kurt Goldstein. Sci Context. 1999;12(4):645-60. https://doi. org/10.1017/S0269889700003641

18. Merleau-Ponty M. Phenomenology of Perception. London: Routledge; 1966.

19. Gurwitsch A. Gelb-Goldstein's Concept of "Concrete" and "Categorical" Attitude and the Phenomenology of Ideation. In: Simmel ML, editor. The Reach of Mind: Essays in Memory of Kurt Goldstein. Berlin: Springer;1968. p. 119-42.

20. Frisch S. Die Suche der Neuropsychologie nach sich selbst. Neurol Rehabil. 2015 Jan;21(6):317-26. 